\title{
Ice Island Calvings and Ice Shelf Changes, Milne Ice Shelf and Ayles Ice Shelf, Ellesmere Island, N.W.T. \\ MARTIN O. JEFFRIES ${ }^{1}$
}

(Received 14 November 1984; accepted in revised form 11 April 1985)

\begin{abstract}
Analysis of vertical air photographs taken in 1959 and 1974 reveals that a total of $48 \mathrm{~km}^{2}$, involving $3.3 \mathrm{~km}^{3}$, of ice calved from Milne and Ayles ice shelves between July 1959 and July 1974. In addition, Ayles Ice Shelf moved about $5 \mathrm{~km}$ out of Ayles Fiord. It still occupied this exposed position in July 1984. The ice losses and movements have allowed the growth of thick sea ice that has developed an undulating topography similar to but smaller scale than that of the ice shelves. It is suggested that regular monitoring of the coastal ice of northern Ellesmere Island would enable such changes to be registered and assessed, as they could be of concern to offshore operations in the Beaufort Sea
\end{abstract}

Key words: air photographs, Milne Ice Shelf, Ayles Ice Shelf, ice island calvings, thick sea ice growth

RÉSUMÉ. Une analyse de photographies aériennes verticales prises en 1959 et 1974 révéla qu'un total de $48 \mathrm{~km}^{2}$, comprenant $3.3 \mathrm{~km}^{3}$, de détacha des plateaux de glace Milne et Ayles entre juillet 1959 et juillet 1974. De plus, le plateau de glace Ayles se déplaça de quelque $5 \mathrm{~km}$ à l'extérieur du fjord Ayles. Le plateau occupait toujours cette position en juillet 1984. Le vêlage et les déplacements de la glace ont permis la formation d'une épaisse glace marine qui a développé une topographie vallonnée semblable à celle des plateaux de glace, mais à une plus petite échelle. Il est suggéré que la surveillance régulière de la glace côtière du nord de l'île d'Ellesmere permettrait l'enregistrement et l'évaluation de tels changements puisqu'ils pourraient affecter les opérations dans la mer de Beaufort.

Mots clés: photographies aériennes, plateau de glace Milne, plateau de glace Ayles, vêlage d'îles glaciales, formation de glace marine épaisse

Traduit pour le journal par Maurice Guibord.

\section{INTRODUCTION}

The historical evidence of Aldrich and Peary, who travelled along the north coast of Ellesmere Island in 1875-76 and 1906 respectively, leaves little doubt that a once extensive ice shelf fringed the coast from Point Moss to Nansen Sound (Fig. 1) (Koenig et al., 1952). During the present century the "Ellesmere Ice Shelf' has disintegrated, creating many ice islands that circulate in the Arctic Ocean, leaving only smaller, individual

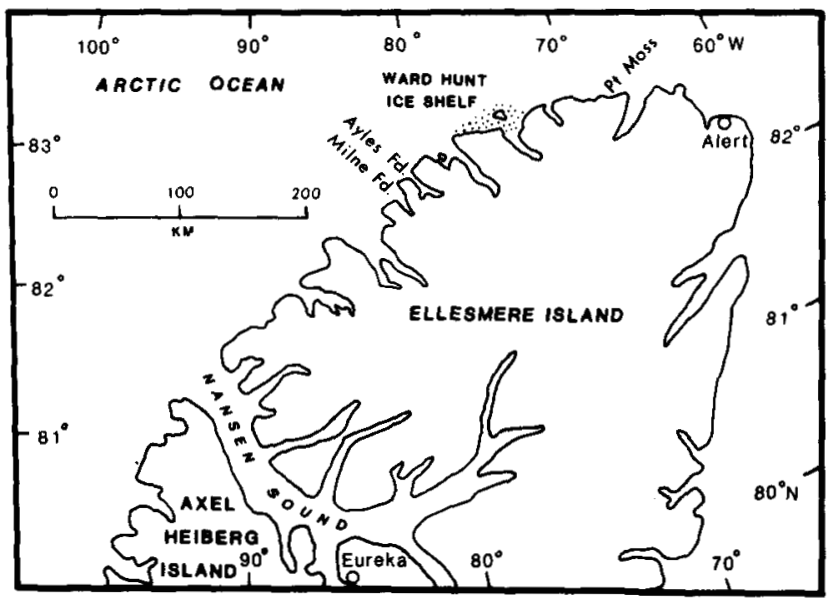

FIG. 1. Map of northern Ellesmere Island, including the location of Ward Hunt Ice Shelf, Milne Fiord and Ayles Fiord between Point Moss and Nansen Sound.

ice shelves. The largest observed ice island calving occurred at Ward Hunt Ice Shelf (Fig. 1), where almost $600 \mathrm{~km}^{2}$ of ice broke away at some time between August 1961 and April 1962 (Hattersley-Smith, 1963). Almost all arctic ice shelf research has been undertaken on Ward Hunt Ice Shelf, while the remaining ice shelves have been photographed from the air or observed briefly in passing during dog-sled and snowmobile traverses of the coastal ice (Hattersley-Smith, 1955, 1962; Serson, 1983). It is the purpose of this paper to draw attention to Milne Ice Shelf and Ayles Ice Shelf, where considerable changes that occurred between July 1959 and July 1974 remained unobserved until recently.

\section{ICE ISLAND CALVINGS AND ICE SHELF CHANGES, 1959-74}

\section{Air Photographs}

In August 1950 trinetrogon air photographs of the ice shelves

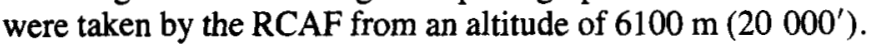
In July 1959 comprehensive air photograph coverage of the ice shelves was taken during RCAF flights along north-south flight lines at an altitude of $9000 \mathrm{~m}\left(30000^{\prime}\right)$. In July 1974 flights along the north coast of Ellesmere Island included photography of only the ice fronts of Milne and Ayles ice shelves. This photography was taken at an altitude of a little over $3000 \mathrm{~m}$ $\left(10000^{\prime}\right)$ by A.C.D. Terroux of the Snow and Ice Division, National Hydrology Research Institute, Environment Canada. Material from each of these occasions is used in this paper.

\section{Milne Ice Shelf}

Figures $2 \mathrm{~A}$ and $3 \mathrm{~A}$ show the outer part of Milne Ice Shelf as it appeared in 1959. The undulating surface of parallel troughs and ridges is very clear as meltwater in the troughs creates a darker tone than the ridges. The $2.5 \mathrm{~m}$ amplitude, $300 \mathrm{~m}$ wavelength undulations are interrupted by both rehealed and open fractures that are partly filled with water. The fracturing of the ice shelf has created a piece of ice (Area A, Figs. 2A and 3A) that appears to be only weakly attached, probably in part by sea ice, to the ice shelf and Cape Evans. A comparison of Figures $2 A, 2 B$ and $3 A, 3 B$ clearly shows that the front of Milne Ice Shelf underwent some change between 1959 and 1974. Area A,

${ }^{1}$ Department of Geography, University of Calgary, Calgary, Alberta, Canada T2N IN4. Present address: Geophysical Institute, University of Alaska 

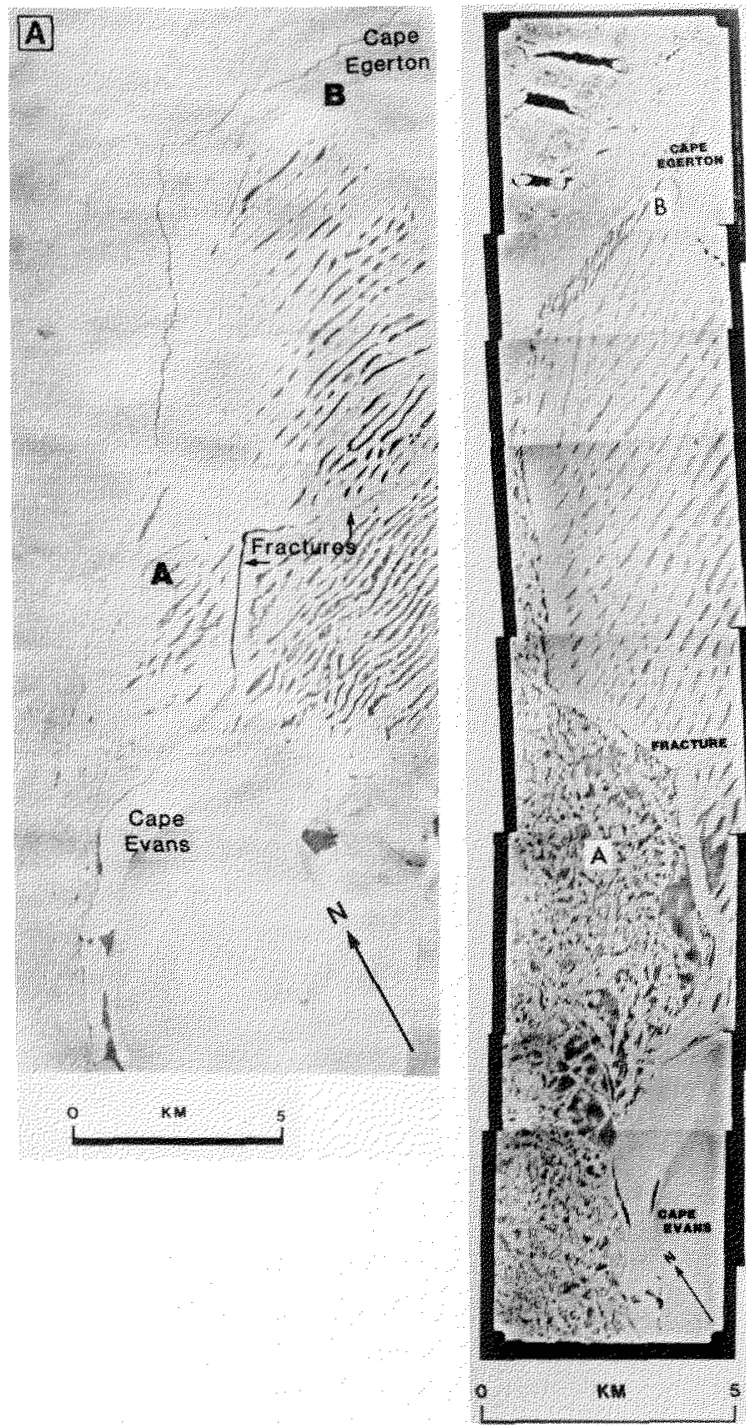

B

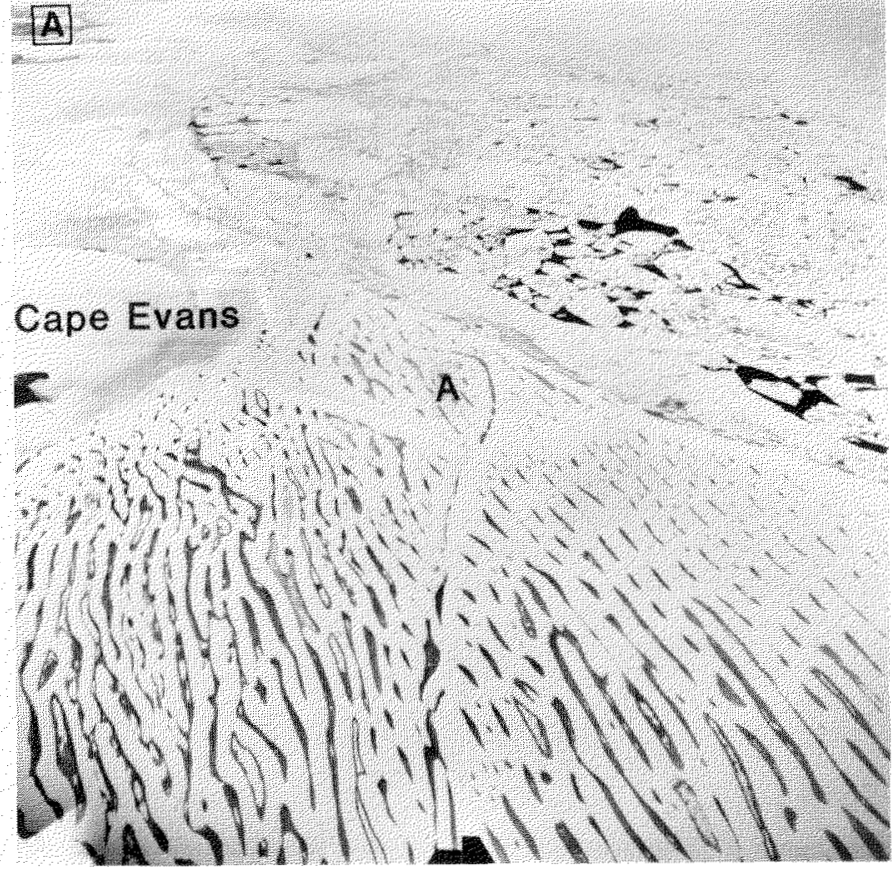

FIG. 3A. Oblique air photograph of the NW front of Milne Ice Shelf, August 1950

Shelf is probably more similar to Ward Hunt Ice Shelf and, therefore, $45 \mathrm{~m}$ in thickness. Assuming such an ice thickness, Area $\mathrm{C}$ had a volume of about $0.8 \mathrm{~km}^{3}$. In addition to the ice island calving, there has been a northward movement of the ice shelf out of the fiord. Area D (Figs. 4A and 4B), once contiguous with the shoreline south of Cape Fanshawe Martin, has moved about $5 \mathrm{~km}$ northwest into the Arctic Ocean (Figs. 4B and 5B).

\section{Recent Ice Growth}

In Milne Fiord and Ayles Fiord the ice island calving and ice shelf movement respectively created large areas that have become filled with new ice (Area A, Figs. 2B and 3B; Area E, Figs. 4B and 5B). This recent ice exhibits an undulating topography where the ridges separate troughs filled with meltwater. Although the topography of Area A is not quite so well devel-

once precariously attached to the ice shelf, calved, creating an ice island with dimensions of about $3.75 \times 8.75 \mathrm{~km}$, an area of almost $33 \mathrm{~km}^{2}$. Ice thicknesses of $60-100 \mathrm{~m}$, due to the influence of glacier tongues (Jeffries, 1982), have been measured by radio-echo sounding of much of Milne Ice Shelf (Prager, 1983). Thus, assuming an average ice thickness of $75 \mathrm{~m}$, the ice island probably had a volume of about $2.5 \mathrm{~km}^{3}$.

\section{Ayles Ice Shelf}

Ayles Ice Shelf (Figs. 4A and 5A) has a similar surface topography to Milne Ice Shelf. Not only are there ridges and troughs but also a series of fractures; the most obvious crack is S-shaped and curves from the northeastern margin to the southwestern margin, and a second linear crack can be detected parallel to and about $1.5 \mathrm{~km}$ to the rear of the ice front. In 1974 Ayles Fiord remained almost completely blocked by shelf ice (Fig. 4B), but a comparison with Figure 4A indicates that changes also occurred here between 1959 and 1974. By 1974 the piece of ice in Area $\mathrm{C}$ had broken away from the ice shelf, creating an ice island with dimensions of $1.5 \times 10 \mathrm{~km}\left(15 \mathrm{~km}^{2}\right)$. The ice thicknesses of Milne Ice Shelf are exceptional; Ayles Ice

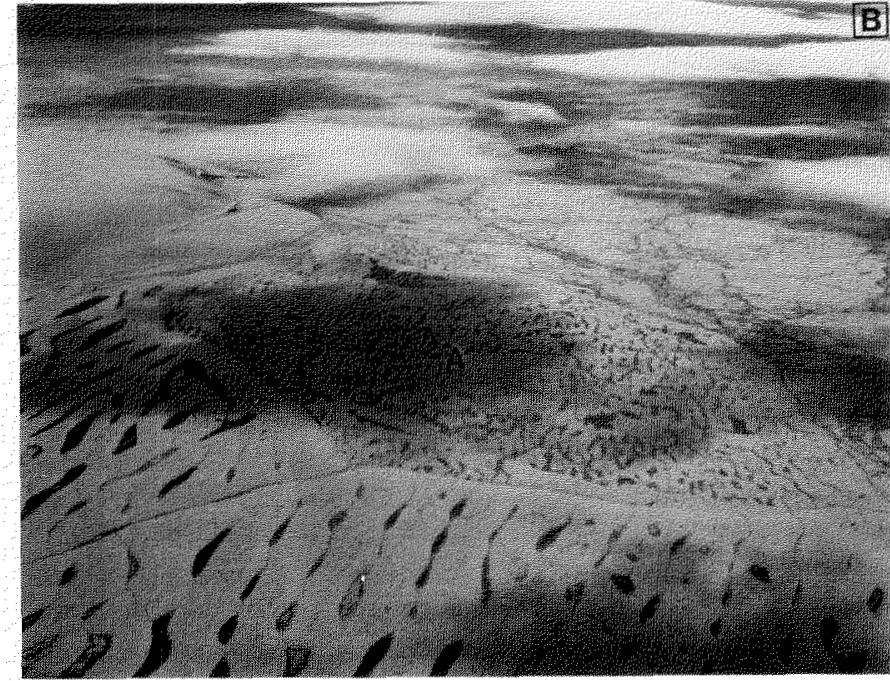

FIG. 3B. Oblique air photograph of the NW front of Milne Ice Shelf, July 1984. 


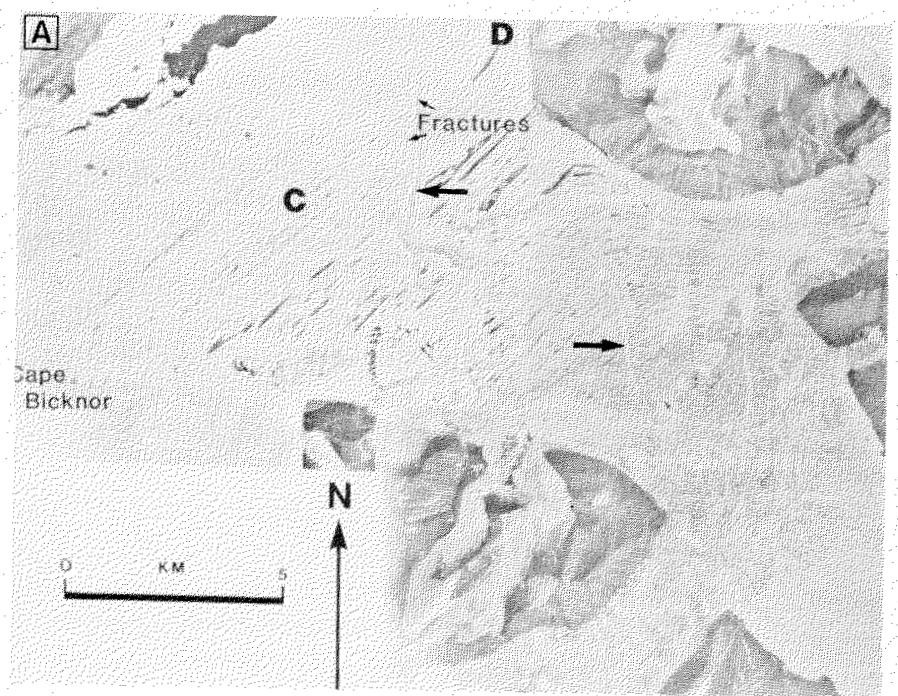

FIG. 4A. Photomosaic of Ayles Ice Shelf, July 1959. The large arrows point to the S-shaped crack.

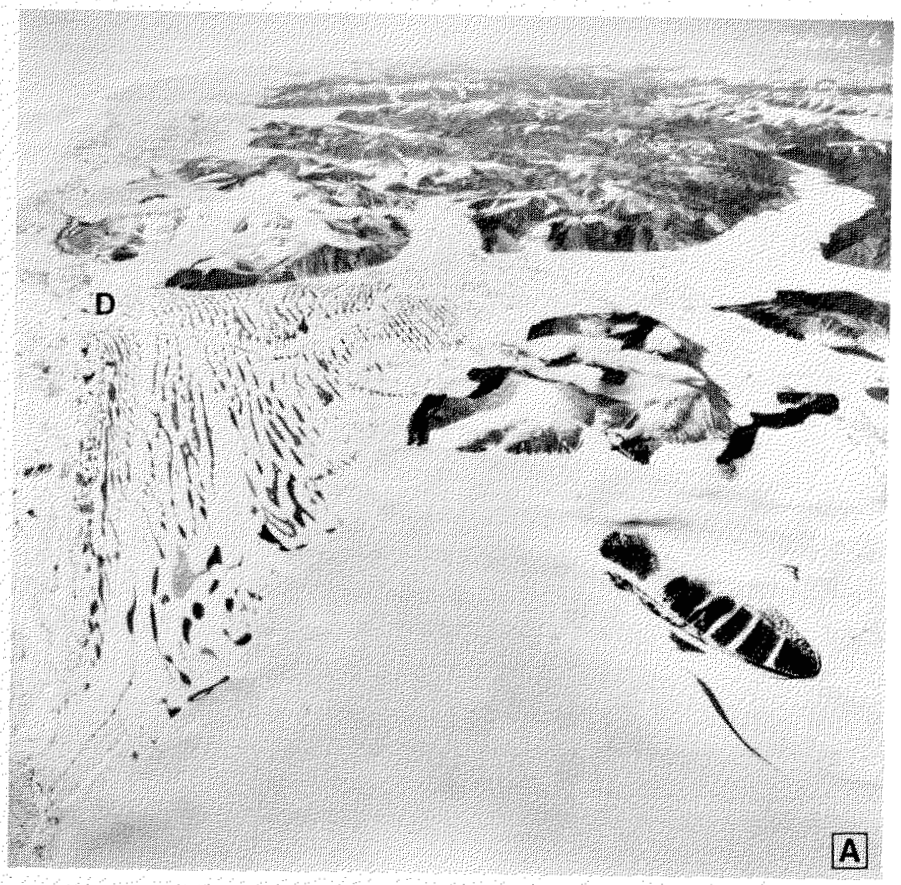

FIG SA Oblique air photograph of Ayles Ice Shelf, August 1950.

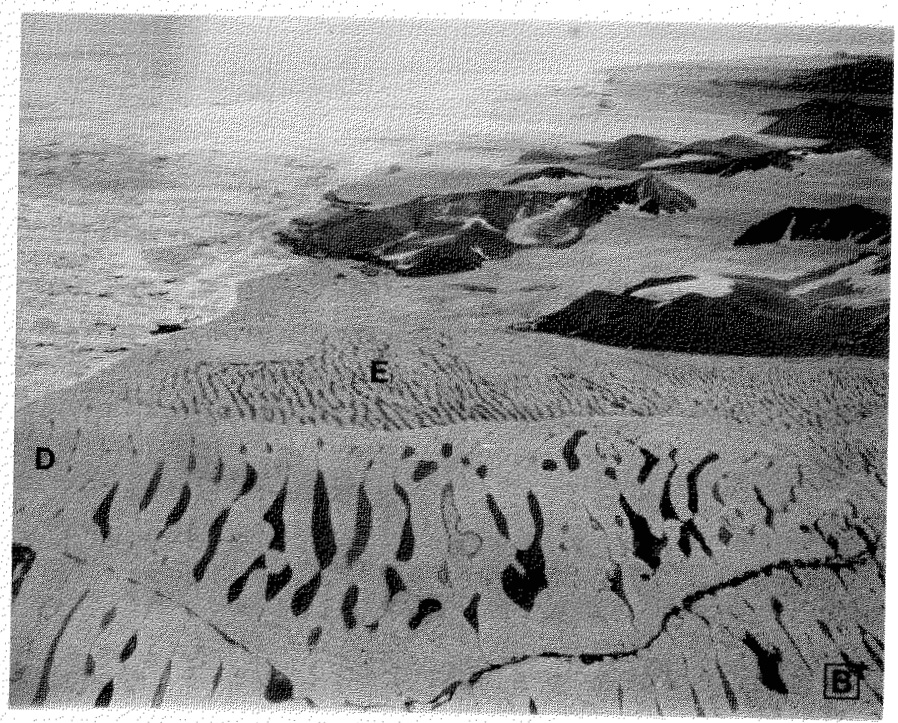

FIG. 5B. Oblique air photograph of Ayles Ice Shelf, July 1984.

oped as on Area $E$, the undulating surfaces of both areas have a wavelength of $60-100 \mathrm{~m}$ and an amplitude of up to $0.5 \mathrm{~m}$. Recent ice core studies of Area A show that the ice has a salinity range of $0.1-2.84 \%$ and a mean salinity of $1.2 \%$ (Jeffries, unpubl. data). There does not appear to be any undulating ice in Area C (Fig. 4B). The presence of a large lead and pack ice here suggests that the ice island calving occurred after the ice shelf movement. By July 1984 Area C was filled with multiyear sea ice.

\section{DISCUSSION}

The cause of the massive calving of ice from Ward Hunt Ice Shelf has been attributed to the coincidence of tidal and seismic events in February 1962 that created a critical condition in the ice shelf and ultimately caused the calving event (Holdsworth, 
1971). The same tidal and seismic phenomena possibly affected Milne and Ayles ice shelves also. Between June 1966 and June 1967 the possible loss of a $2 \mathrm{~km}$ wide band of ice from the front of Milne Ice Shelf was observed by H. Serson (Sackinger $e t$ al., 1984). It is possible that the changes at Milne and Ayles ice shelves did not occur until four or five years after the events at Ward Hunt Ice Shelf. Although the tidal and seismic events of 1962 perhaps weakened the ice, there was a delay before the final dislodgement and movement. In 1966 only scattered ice islands and slivers of ice shelf were observed in Ayles Fiord (Hattersley-Smith, 1967). Hattersley-Smith concluded that Ayles

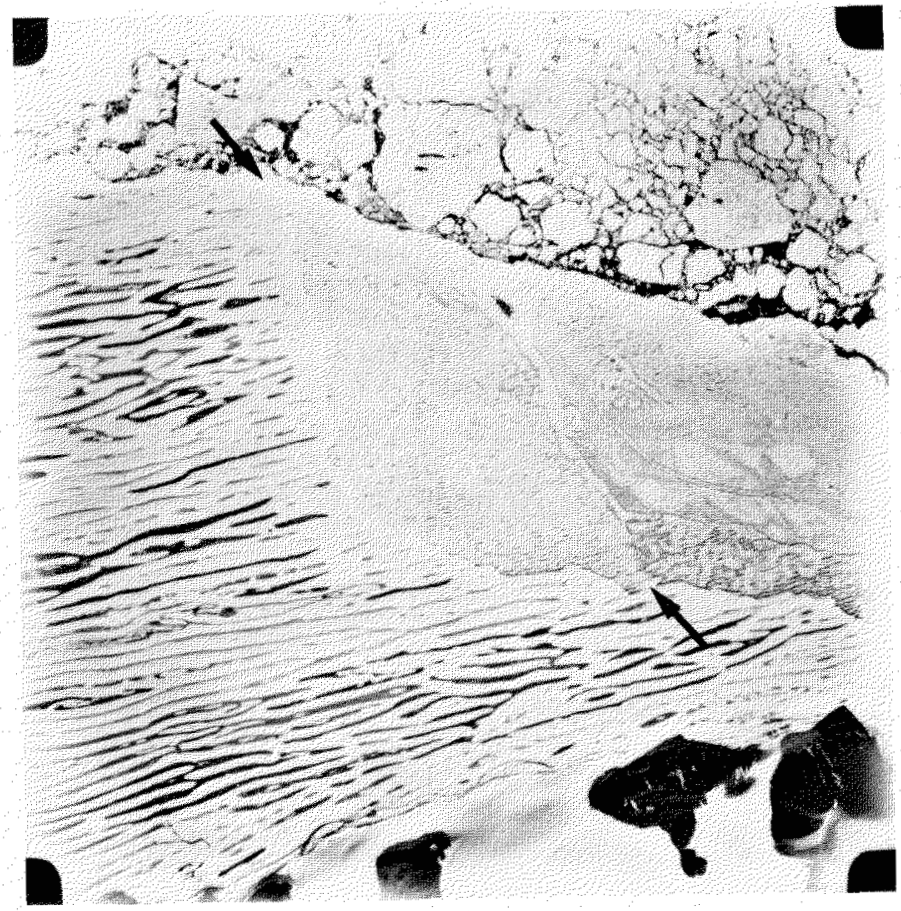

FIG. 6. Vertical air photograph of Markham Bay Re-entrant, July 1959. The distance between the arrows is about $7 \mathrm{~km}$.

Ice Shelf no longer existed, but this is now known not to be the case. Much of Ayles Ice Shelf, an area of about $100 \mathrm{~km}^{2}$, remains in the mouth of Ayles Fiord but in a more exposed position than in 1959.

After an ice island calving in 1946 (Koenig et al., 1952), sea ice grew to a thickness of $11.25 \mathrm{~m}$ in 14 years in the Markham Bay Re-entrant (Fig. 6) at the east end of Ward Hunt Ice Shelf (Fig. 1) (Lyons and Ragle, 1962). The re-entrant ice has an undulating topography with a wavelength of about $60 \mathrm{~m}$, in sharp contrast to the adjacent ice shelf but remarkably similar in appearance to the sea ice of Areas A and E (Figs. 2B and 4B). The Milne Re-entrant was about $9 \mathrm{~m}$ thick in May 1983 (J. Thorleifsson, pers. comm.), and since Areas A and E have a similar surface topography they are probably of a similar age and thickness. Although it is not the purpose of this paper to explain the growth of such great thicknesses of sea ice, it is worth noting that the ice exceeds the $2.5-5.0 \mathrm{~m}$ steady-state thickness of undeformed multiyear sea ice (Maykut and Untersteiner, 1971). However, Walker and Wadhams (1979) have shown that even under present climatic conditions, undeformed sea ice can reach thicknesses of at least $20 \mathrm{~m}$. Clearly, thick sea ice is common in this region of the Canadian Arctic and includes Areas $A$ and $E$ and a plug of 6-10 $\mathrm{m}$ ice in the mouth of Nansen Sound (Fig. 1) (Serson, 1972).

\section{CONCLUSION}

During the period $1959-74$ some $48 \mathrm{~km}^{2}$, involving $3.3 \mathrm{~km}^{3}$, of ice calved from Milne and Ayles ice shelves and the remainder of Ayles Ice Shelf moved some way out of the mouth of Ayles Fiord. Although the total loss of ice from these events is much less than the massive loss from Ward Hunt Ice Shelf, it still constitutes a considerable loss, indicating the ice shelves remain unstable and prone to disintegration. In 1982 Area B (Fig. 2B) was severely fractured and considered likely to disintegrate. This had occurred by spring 1985. Despite the large change at the front of Ward Hunt Ice Shelf in 1962, the ice front remains changeable, since between 1980 and 1983 a total of about $80 \mathrm{~km}^{2}$ of ice was lost, including three large ice islands (Jeffries and Serson, 1983).

Any ice front can be expected to be unstable, and the periodic calving of ice islands and thick sea ice might be a normal process akin to, but smaller scale than, iceberg calvings from a glacier. Further losses from the ice shelves and landfast sea ice of northern Ellesmere Island are to be expected, and it is clear that there is a quite rapid degeneration of thick sea ice where calvings occur. These events and processes are not to be taken lightly, since the periodic calving of ice and the regrowth of thick sea ice is of concern to the exploration for and development of offshore resources in the Beaufort Sea, where offshore structures and vessels might be threatened by the pack ice, thick sea ice floes and ice island hazards. In addition to monitoring ice island drift, it is considered that regular ground and air surveys represent an effective means of assessing the frequency and magnitude of calving events from the ice margins of the northern Ellesmere Island coast.

\section{ACKNOWLEDGEMENTS}

Work on the northern coast of Ellesmere Island would not have been possible without the moral, financial and logistic support of the following individuals and organizations: S.A. Harris, H. Serson and G. Holdsworth, who read an early version of the manuscript; the Polar Continental Shelf Project; Arctic Acoustics Section, Defence Research Establishment Pacific; Dome Petroleum Ltd.; Gulf Canada Resources Ltd.; Petro-Canada; the Arctic Institute of North America; the Department of Geography, University of Calgary.

\section{REFERENCES}

HATTERSLEY-SMITH, G. (with A.P. Crary and R.L. Christie). 1955. Northern Ellesmere Island 1953 and 1954. Arctic 8:1-36.

HATTERSLEY-SMITH, G. 1962. Ice conditions off the north coast of Ellesmere Island. Ottawa: Defence Research Board. D. Phys. R(G) Report No. Misc. G-8. $21 \mathrm{p}$.

1963. The Ward Hunt Ice Shelf: recent changes of the ice front. Joumal of Glaciology 4:415-424.

1967. Note on ice shelves off the north coast of Ellesmere Island. The Arctic Circular XVII:13-14.

HOLDSWORTH, G. 1971. Calving from Ward Hunt Ice Shelf, 1961-1962 Canadian Journal of Earth Sciences 8:299-305.

JEFFRIES, M. 1982. Ward Hunt Ice Shelf, spring 1982. Arctic 35:542-544.

JEFFRIES, M.O., and SERSON, H. 1983. Recent changes at the front of Ward Hunt Ice Shelf, Ellesmere Island, NWT. Arctic 36:289-290.

KOENIG, L.S., GREENAWAY, K.R., DUNBAR, M., and HATTERSLEYSMITH, G. 1952. Arctic Ice Islands. Arctic 5:67-103

LYONS, J.B., and RAGLE, R.H. 1962. Thermal history and growth of the Ward Hunt Ice Shelf. International Union of Geodesy and GeophysicsInternational Association of Hydrological Sciences, Colloque d'Obergurgl, 10-18 September 1962. 88-97.

MAYKUT, G.A., and UNTERSTEINER, N. 1971. Some results from a timedependent thermodynamic model of sea ice. Journal of Geophysical Research 76:1550-1575. 
PRAGER, B.T. 1983. Digital sigǹal processing of UHF radio echo sounding data. Unpubl. M.Sc. Thesis. Department of Geophysics and Astronomy, University of British Columbia. $88 \mathrm{p}$.

SACKINGER, W.M., STRINGER, W.J., and SERSON, H. 1984. Arctic ice island and sea ice movements and mechanical properties. Fairbanks: Geophysical Institute, University of Alaska. 2nd Quarterly Report submitted to U.S. Dept. of Energy, Morgantown Energy Technology Center, West Virginia. $210 \mathrm{p}$.
SERSON, H.V. 1983. Ice conditions off the north coast of Ellesmere Island, spring 1980. Defence Research Establishment Pacific. Technical Memorandum 83-8. $23 \mathrm{p}$.

1972. Investigation of a plug of multi-year old sea ice in the mouth of Nansen Sound. Defence Research Establishment Ottawa. Technical Note 72-6. $15 \mathrm{p}$.

WALKER, E.R., and WADHAMS, P. 1979. Thick sea ice floes. Arctic 32:140-147. 